\title{
創薬，育薬の立場から薬系大学院教育に望むもの
}

\author{
大森健 守
}

\section{Expectations for the Education of Graduate School of Pharmaceutical Sciences from the Viewpoint of Discovery and Development of New Drugs}

\author{
Kenji OHMORI \\ Department of Pharmacology, Yokohama College of Pharmacy, 601 Matano-cho, \\ Totsuka-ku, Yokohama 245-0066, Japan
}

(Received October 7, 2010)

\begin{abstract}
For the purpose of the development of new drugs for incurable diseases, many students enter graduate school of pharmaceutical sciences every year. At first, I expect education to let it develop more and spread without forgetting this will. Recently, withdrawals from Japan of the research institutes of the foreign-affiliated pharmaceutical companies have occurred successively. It is pointed out that there is it for the study about the biomedical research that is the next step of fundamental researches having been weak. I expect the immediate construction of the cluster, which consists of pharmaceutical companies and graduate schools of pharmaceutical sciences. Time of ten several years and a cost of one hundred billion yen are necessary for the research and development of new drug. The success probability is low, besides. Many trials are accomplished to raise the success probability. The one is introduction of the project system. The best members are gathered from the fields such as medicinal chemistry, molecular biology, biochemistry, pharmacology, pharmacokinetics, pharmaceutics and toxicological sciences, etc. The project system is a system enforcing go or stop by own judgment, an authority and the responsibility of the purpose are given. It is necessary for the project leader to have great knowledge and the abilities to hold lively discussion. It is a researcher from graduate school of pharmaceutical sciences that is the most suited to be as a project leader. I expect to upbring education from the time when a leader is young.
\end{abstract}

Key words—_ discovery and development of new drug; biomedical; project system

日本薬学会の「薬学用語解説」では, 新しい薬を 開発するための基礎研究, 臨床試験等, 医薬品が発 売されるまでの研究開発の過程を創薬と言い，既に 市販された医薬品について医師，薬剤師，製薬企業 関係者，研究者，患者らがそれぞれの立場で薬をよ り使い易く, 有効性及び安全性の高いものに育てて いく様々な取り組み（制度，活動）を育薬と定義さ れている，本論文では，製薬企業において創薬，育 薬に従事してきたものとして薬系大学院の教育・研 究への期待することについて私見を述べる，筆者は 成績が悪く母校の薬系大学院入試に失敗し, 薬学部 卒業後直ちに企業（協和発酵工業侏，当時）に入社

横浜薬科大学薬理学教室（干245-0066 横浜市戸塚区俣 野町 601)

e-mail: yoshie.omori@ny.thn.ne.jp

本総説は, 日本薬学会第 130 年会シンポジウム S 24 で 発表したものを中心に記述したものである.
してその研究所で約 35 年間の薬理研究人生を過ご してきた.

不治の病を治療する新薬の開発を目指し，毎年多 くの学生が薬系大学院に進学する.この「志」を忘 れず，さらに発展拡大させる薬系大学院の教育をま ず望むものである.

日本の製薬企業を取り巻く環境は大きく変化して いる，その 1 つは，売上高が年間 10 億ドルを超え ブロックバスターと呼ばれる医薬品が 2010 年前後 に特許満了を迎えることである。 ランソプラゾー ル, ビオグリタゾン, カンデサルタン，タムスロシ ン, タクロリムス, アトルバスタチン, ドネペジ ル，ラベプラゾール，レボフロキサシンなどの医薬 品であり企業業績に影響することは必至である。さ らにこの問題の本質は特許切れをカバーする新薬が 出てこないことであると考えられている. ${ }^{1)} 2 \supset$ 目 は後発医薬品（ジェネリック医薬品）の使用促進と 
いう施策である。 2012 年にジェネリック医薬品の 使用を数量べースで $30 \%$ まで引き上げることを目 標とし，そのため 2010 年 4 月には使用促進を目的 とした診療報酬改定が施行された。一方で新薬創 出・適応外解消等促進加算が新設され, 本加算によ つて製薬企業はより早く次の開発原資を得ることが でき研究開発に集中できる環境が整備された。これ ら相反する施策によって新薬開発がどのように推移 するか見守っていきたい. 3 つめは外資系製薬企業 の研究所が 2004 年以降日本から撤退し，その拠点 を中国やアジア諸国を移していることである（Table 1). 1980 年代に彼らが日本に進出してきた理由 には，日本には優秀な研究者が豊富であることや日 本の医薬品市場が世界第 2 位であることなどが挙げ られる，撤退理由については，日本の医薬品市場は 依然世界第 2 位をキープしているがそのシェアは 10 年前に比べ半減していること，世界のメガフ アーマでさえ研究員を中心に 10000 人規模の人員削 減に動いていること，ICH（日米欧医薬品規制調和 国際会議）で日米欧 3 極の医薬品申請資料の相互利 用が可能であるという合意がなされたこと，中国や インドを中心に欧米帰りの優秀な人材が育成されて きたことなどが関係していると考えられる．研究所 の日本からの撤退に関し，2007 年 2 月 13 日付の日 刊薬業に興味深い記事があったので紹介する。欧州 製薬団体連合会日本支部会長で，グラクソ・スミス クライン日本法人のマーク・デュノワイエ会長は記 者会見で，「欧州などの製薬企業が日本の研究施設 を撤退させる一方，ほかのアジア諸国への投資を強 化している理由について，基礎研究の次のステップ であるバイオメディカル (生物医学) の研究が欠け ていたためで生産性の問題ではない。中国や韓国 は，バイオメディカル研究の必要性を理解し，日本

Table 1. List of the Foreign-affiliated Pharmaceutical Companies that Withdrew from Japanese Research Institutes

\begin{tabular}{l|l}
\hline \multicolumn{1}{c|}{ Institutes } & Year \\
\hline Bayer Kyoto research institute & 2004 \\
Bayer Kobe research center & 2007 \\
GlaxoSmithKline Tsukuba institute & 2007 \\
Pfizer Nagoya central institute & 2008 \\
Novartis Tsukuba institute & 2008 \\
Merck Tsukuba institute & 2009
\end{tabular}

より早く環境整備を進めた. バイオメディカル研究 を行うには大学や企業のクラスター（集合体）の存 在が有用であり，日本でもこうしたクラスターでの 研究を積極的に行っていれば研究はもっと成功した のではないか」と述べている，筆者も同意見である.

バイオメディカルは基礎研究と臨床医学をつなげ るものであり，臨床効果の予測性を高める分野であ る. ${ }^{2)}$ 医学系, 工学系, 理学系, 農学系などの他の 大学院の教育では希薄であり, 薬系大学院の研究や 教育が最も得意とする分野である。ぜひ，今後とも 注力してもらいたい。具体的には，ADME（吸収・ 代謝・分布・排泄）や薬物相互作用に関する薬物動 態研究，DDS（ドラッグデリバリーシステム）な どに関する製剂研究，毒性・安全性研究，薬効評価 を行う薬理研究などの分野である。これらの学問を 総合的に習得した大学院生が研究を進める合成研 究, 薬品分析研究, 物理化学研究にも期待するとこ ろが大である。

現代の克服すべき疾患はがん，自己免疫疾患，ア ルツハイマー症，うつ病などの多因子疾患である. その原因の 1 つが動物実験の難しさであり，ヒトの 疾患に相似したインビボ（in vivo）疾患動物モデ ルの構築が待たれている。主たる発症因子，その増 悪因子，疾患関連遺伝子，病態，症状などについて 多面的にヒトとの相似性が検証されるが，すべての 条件を満たすモデルは極めて少ない，筆者の担当で あった気管支喘息治療薬の領域では，IgE 抗体の産 生能はマウス，ラットに比ベモルモットは低く，呼 吸器系の機能はモルモットの方がマウス，ラットに 比べヒトに類似しているという性質があり，化合物 の薬効評価には複数の動物モデルが必要であった。 そのため化合物の効果が動物モデルによって相反す るケースがあり，開発候補化合物の最適化という段 階で多くの苦労をした。疾患動物モデルの構築は一 見地味なテーマであるが, 総合的な研究が必要であ り薬系大学院で注力して頂きたい分野である.

日本は，官界でも学界でも縦割り組織が中心で, 伝統的にヨコのつながりや組織横断的な取り組みが 弱かった，一方，多くの民間企業ではフラットかつ 横断的な相互協力体制，プロジェクト体制がとられ ている，期限・予算の権限が委譲され，組織図に現 れる各部署はプロジェクトをバックアップし，プロ ジェクトに対する評価は給与に反映される体制であ 
る，筆者の経験を基に製薬企業におけるプロジェク 卜制について紹介したい。このシステムは多くの同 業他社でも実施されているものである，製薬企業の 研究所においては研究所長の下，有機合成，分子生 物学, 生化学, 薬効評価, 薬物動態, 製剂, 安全性 などの研究部門が置かれる（Fig. 1)。各部門の管 理職はルーティン業務と人材育成を担当するが，が ん，腎臓・心臟疾患，アレルギー，炎症，脳疾患な ごの多種多様な研究テーマへの対応には自ずから限 界がある。そこで各部門から得意分野を持つ 1-2名 の研究員が集められプロジェクトが結成される，メ ンバー全員がプロジェクト全体を把握でき，かつ自 由度が高く自立的に仕事ができる体制であるが，そ の存続は期間限定的である．プロジェクトが結成さ れると，その中心となるプロジェクトリーダーが選 任される。プロジェクトリーダーには，出身部門の みならず他部門の研究に通暁し，研究員と細部に至 るまで討論ができてその信頼を得る能力が必要であ る.このプロジェクトリーダーに最もふさわしいの が薬系大学院出身者であると筆者は考える.薬学部 には新薬開発の志を持って入学してくること，大 学，大学院時代に幅広い領域を勉強するので基礎研 究と臨床研究を俯瞰できることなどがその理由であ る．創薬に行き詰まった場合には出身の薬系大学院 の教官，先輩，同級生に相談できることも強みであ る.もちろん, 理学系, 工学系, 農学系などの大学 院で生命科学を履修してきた研究員に対しては新入 社員時代のみならず 2,3 年毎に定期的な教育が実 施されるが，専門分野に特化しがちであり幅広い知

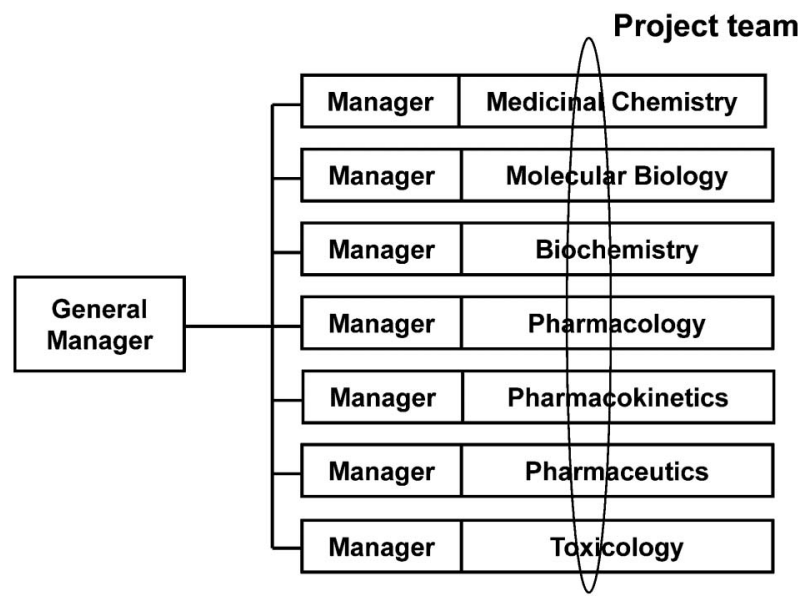

Fig. 1. The Projective System for Discovery and Development of New Drugs in Pharmaceutical Company
識を得ることは困難である。

プロジェクトリーダーに必要なことはストレスに 耐える心の涵養である．創薬を進めていく過程で多 くの問題に直面する。例えば， 2 年間スクリーニン グを続けても既存薬や競合薬の活性を上回る化合物 が出ない，出たとしてもその合成コストが高い，バ イオアベイラビリティが低い, in vivo の疾患モデ ルで効かない，作用持続時間が短い，安全性試験で 予想もしない副作用が出るなどの問題である。これ ら諸問題が解決され臨床試験（治験）に進んでも， 有効性と安全性が確認できずドロップアウトする薬 物が多い。なにせ 20000 個の化合物のうち 1 化合物 だけが上市できる世界である，筆者もプロジェクト リーダーを務めたが，化合物が薬物へと進化する段 階毎のキーオープンの 1 週間前から不安感と不眠に 悩んだ．ストレスに耐える心の涵養が必要であるこ とを実感した。

幸い薬物の開発が順調に進んだとしても，その成 果をなかなか学会発表や論文にすることはできな い，企業秘密，特に特許取得の問題である，競合他 社から改良薬が出される恐れがある，早く取得し過 ぎて独占販売期間が短縮するなどの問題から外部発 表は規制される，アカデミアに進んだ同級生の華々 しい発表を横目で見なければならない。さらに，研 究がうまく進展せず解散間際のプロジェクトに発表 の機会が与えられることもある。このような研究に は限界がありますということを周知させるものでそ れなりの意義のあるものであるが，うまく進んでい るプロジェクトのチームリーダーはその発表も横目 で見なければならない。これもストレスになる。

プロジェクトリーダーには説明・発表能力の資質 も必要である，研究がうまく進展しない場合，期間 延長を会社幹部に要請し支援を得る。あと 1 年間, 少なくとも半年間のプロジェクト期間延長を依頼す るわけである。今風に言えば，事業仕分け人の前で 進行状況を的確に説明し，プロジェクトの廃止や縮 小を避けるわけである。逆に研究がうまく進展して いる場合には，国内外同業企業への導出も図られる が，その交渉の場ではプロジェクトリーダーが研究 内容を紹介する．筆者も米国テキサス州フォート ワースにある企業への導出時にその経験をしたが, 語学力の不足とともに説明能力の乏しさに冷や汗を かいた. 
わが国において, 今後ますますプロジェクト制が 定着しプロジェクトリーダーが重要な役割を果たす と考えられる. しかし, プロジェクトリーダーに必 要な資質は一朝一夕に身に付くものではない. 薬系 大学院においては組織横断的な研究チーム作りとそ のチームリーダーに大学院生も就任できるような環 境作りを望みたい.

基礎研究や創薬研究の初期のみならず, 創薬研究 の後期や育薬の段階も薬系大学院出身者の能力を発 揮できる場である。その 1 つは臨床開発部門であ る. 臨床試験（治験）では, 非臨床試験を通過した 物質についてヒトに対して安全性と有効性があるか ぞうか調べられる，おおよそ 3-7 年が必要である. ヒトを対象とした治験については, 薬事法上の規制 だけでなく, 被験者の人権, 安全性及び福祉の保護 の下に科学的に適正でかつ倫理的な試験を実施し, データの信頼性を高めるために設けられた基準 GCP（Good Clinical Practice）に従って進めなけ ればならない。ここでも薬系大学院出身者の幅広い 知識が生かされる.

特許, 知的財産部門でも幅広い知識が必要であ る. 医薬品に与えられている主な特許は, 物質特 許, 製法特許, 製剂特許, 用途特許である. 特許権 の存続期間は出願の日から 20 年で, 医薬品には条 件を満たせば 5 年間の延長が認められている. その 間, 特許出願者が独占的に製造, 販売できる権利を 有するためジェネリック医薬品は提供されない。し かし, 医薬品の研究開発には 10-15 年という長期間 を要するので, 早い時期の特許出願の場合は独占的 製造販売の期間は短くなり，早い時期にジェネリッ ク医薬品の市場参入が発生する. 一方, 競合他社に 先に特許を押さえられてしまうとそれ以後の研究は ストップする.さらには先行特許を幅広い範囲で取 得した場合には, 後続する自社の優秀な化合物の特 許が制限されてしまうことが起きる. 日本は技術で 勝ち, 事業で負けると言われる. 特許を収益につな げる知的財産戦略が欠かせない。このように特許出 願について, 出願時期やその範囲には十分な考慮を 払わねばならず, 薬系大学院出身者の知識が必要で ある。

薬系大学院出身者の専門的で幅広い知識は, 育薬 の場である市販後調查 (PMS, Post Marketing Surveillance）においても重要である. 医薬品の製造販
売承認時の有効性, 安全性に関する情報は, 限られ た条件下で実施された臨床試験から収集されたもの で, (1)検討症例数が少ない, (2)年齢, 合併症, 併用 薬などに制限が加えられた患者群での成績である, (3)使用期間が短期である, (4)試験成績が集団として の評価である, (5)専門医による評価である, などの 点で実際の医療の現場とは異なっている. 製造販売 後も引き続き医薬品の有効性, 安全性について調査 し監査していくために市販後調査が導入されてい る. 市販後調查には 3 つの制度, 新医薬品などを対 象とする再審査制度及び安全性定期報告, すべての 医薬品が対象となる再評価制度, 安全性についてモ ニターする副作用・感染症報告制度があり，それぞ れ GPSP (Good Post-marketing Study Practice) と GVP (Good Vigilance Practice) という基準に従つ て実施されている。これらの業務を遂行し必要な情 報を収集し，それらを評価し，すべての医療関係者 に伝達するためには医薬品についての幅広い知識が 必要であり, 薬系大学院出身者が活躍できる業務で ある。

最後に薬系大学院の研究内容の広報活動について 要望したい. 製薬企業の研究所においては, 入社 5 -15 年の研究員を対象として国内外の研究機関に派 遣されることがある. 派遣目的は最新技術や知識の 習得，人的交流の確立であり，その派遣期間は 1-3 年である. 筆者も研究所勤務の後半 15 年間におい て同僚や後輩 20 名の派遣のお手伝いをさせて頂い た. 派遣先の内訳は, 国外の大学, 研究機関に 9 名, 国内の医学部に 8 名, 国内の薬系大学院に 3 名 であった. 薬系大学院への派遣者数が少ないが, そ の理由は学会発表や発表論文を参考にしても, 薬系 大学院の研究内容をしっかりと把握できなかったか らである. 現在では改善がみられ, 研究室の概要が ホームページで紹介されるようになってきたが, 多 くの研究室でその研究内容を公表するシステム作り を要望するものである.

薬系大学院においては, 基礎研究のみならずバイ オメディカル研究, 特に in vivo の研究の充実, プ ロジェクトリーダー育成のための教育や育薬につい ての教育を願うものである. 薬系大学院と製薬企業 の連携によって日本発の多くの医薬品が生み出され ることを期待する. 


\section{REFERENCES}

1) Sato K., "Iyakuhin Crisis," Shinchosha Co., Ltd., Tokyo, 2010, pp. 149-151.
2) Nakayama K., "Atarashii Kusuri o Doutsukuruka," ed. by Kyoto University Graduate School of Pharmaceutical Sciences, Kodansha Ltd., Tokyo, 2007, pp. 17-48. 